\title{
PERJUANGAN UMAT ISLAM UNTUK INDONESIA ABAD 20
}

\author{
Saidul Amin \\ e-Mail : aminsaidul@yahoo.com \\ UIN Sultan Syarif Kasim
}

\begin{abstract}
Abstrak : Gerakan perjuangan untuk kemerdekaan Indonesia tidak bisa lepas dari peranan umat Islam, baik pra kemerdekaan, saat kemerdekaan dan pasca kemerdekaan dalam mempertahankan kedaulatan Indonesia. Hal itu dapat dilihat dari pergerakan yang dilakukan oleh umat Islam baik secara pendekatan politik, organisasi sampai kepada gerakan perlawan terhadap kependudukan penjajah. Lahirnya gerakan tersebut tidak lepas dari faktor-faktor yang mempengaruhi dan mendukung yang berkembang pada masa itu, yang telah melahirkan pergerakan di tengah tengah umat Islam, terutama pada abad ke 20.
\end{abstract}

Kata Kunci : pergerakan, Islam, politik, nasionalisme

\section{Pendahuluan}

Dengan rahmat Allah Swt, rakyat Indonesia diberikan kekuatan untuk membebaskan serta melepaskan diri dari belenggu penjajahan. Berlandaskan keyakinan, tekad yang kuat semangat yang gigih, akhirnya kemerdekaan Indonesia pun bisa dicapai. Kemerdekaan ini tidak serta merta diperoleh begitu saja, banyak lika liku perjuangannya yang harus kita ketahui.

Perjalanan sejarah kemerdekaan bangsa ini tidaklah dalam waktu yang singkat, namun semua ini adalah hasil dari sebuah perjuangan yang panjang, buah dari darah para pejuang bangsa ini. Usaha untuk memperoleh kemerdekaan yang dilakukan tidaklah mudah, pergi berjuang kemedan perang, mengorbankan harta dan nyawa, bukanlah hal yang sepele, semua itu pastinya dengan sebuah pertimbangan yang leih besar, lebih berarti dari harta dan nyawa itu sendiri. Ada sesuatu yang menjadi cambuk penyemangat bagi rakyat Indonesia dalam memperoleh kemerdekaannya yang mesti untuk diketahui. Karena dengan mengetahui perjalanan perjuangan itu kita bisa lebih mengerti arti sebuah kemerdekaan.

Banyak aspek yang terlibat dalam perjuangan ini, banyak kalangan yang terikat, pada akhirnya menghasilkan sebuah gerakan serta cita-cita kemerdekaan yang dilakukan secara bers ama-sama, bahu membahu antara satu dengan yang lainnya. maka dari itu pada kesempatan kali ini, penulis mencoba untuk memaparkan sedikit tentang bentuk perjuangan yang pada akhirnya menghantarkan bangsa Indonesia ini merdeka, siapa orang yang ada dibelakang setiap pergerakan serta apa motifasi yang sangat berpengaruh dalam perjuangan ini.

Tidak hanya berhenti sampai di sini saja, ada hal yang lebih penting 
lagi dari sebuah kemerdekaan, yaitu bagaimana cara mempertahankan kemerdekaan yang dilakukan oleh bangsa dan rakyat Indonesia. akan tetapi, begitu panjang sejarah pergerakan bangsa Idonesia, namun yang akan menjadi bahan tulisan pada kesempatan ini adalah corak perjuangan umat Islam abad 20 sebelum dan sesudah kemerdekaan. Kita mencoba untuk menjawab dari pertanyaan-pertanyaan tentang pengaruh Islam dalam perjuangan dan mempertahankan kemerdekaan bangsa ini. Atas segala kekurangan dan kekeliruan dalam tulisan ini, mohon diberi masukan dan perbaikan.

\section{Bab I. Sebelum Kemerdekaan}

\section{A. Pengaruh Pan Islamisme Timur Tengah}

Sebelum abad 20 diberbagai dunia banyak terjadi revolusi, dan semuanya didominasi dalam bentuk perjuangan untuk memperoleh kemerdekaan, tak terlepas dengan Mesir salah satu negara yang paling berpengaruh di Timur Tengah, berhasil melepaskan dirinya dari pejajahan kolonial Inggris. Perjuangan itu dengan hadirnya pergerakan-pergerakan dari para pembaharu-pembaharu yang lahir pada masa itu, diantaranya adalah Muhammad Abduh. Tidak hanya di Mesir, di India juga diwarnai dengan perjuangan rakyatnya untuk memperoleh kemerdekaan, salah satu tokoh pembaharunya adalah Muhammad Iqbal. Melalui gerakan- gerakan pembaharuan yang diprakarsai oleh hasil pemikiran-pemikiran, yang menjadi cambuk untuk segera memperoleh kemerdekaan dan mengusir penjajah.

Adapun gerakan kemerdekaan yang terjadi di Timur Tengah Khususnya di Mesir, dan India di Asia didorong oleh sebuah gerakan Pan Islamisme yang dipelopori oleh Sayid Amir Ali dan Jamaluddin al Afghani ${ }^{1}$ yang juga memiliki pengaruh terhadap bangsa Indosnesia khususnya Muslim Indonesia. Tidak hanya Mesir dan India saja namun di Makkah sendiri juga terjadi pembaharuan pemikiran, dan pemurnian ajran Islam. Kita menyadari Indonesia dan Mekkah sebenarnya telah berjalin sejak lama, itu bisa dilihat dari jamaah haji yang pergi ke Mekkah. Tidak sedikit dari mereka yang menetap di sana, bahkan dengan kesadaran ingin menuntut Ilmu dan memperdalam ilmu agama, sehingga menghasilkan ulama-ulama dan para pendidik yang berlatar belakang agama. Kehadiran mereka ini membawa pemikiran pembaharuan yang sedang berkembang dan dipelajari di sana, pada akhirnya sangat mewarnai pemikiran dan perjuangan umat Islam Indonesia dalam menghadapi penjajah. Abdul Sani mengungkapkan:

$$
\begin{array}{r}
\text { "...sangat wajar, } \\
\text { kalau persentuhan- }
\end{array}
$$

1 M. Abdul Karim, Islam dan kemerdekaan Indonesia: Membongkar Marjinalisasi Peranan Islam Dalam Perjuangan Kemerdekaan RI (Yogyakarta : Sumbangsih Press, 2005), hlm. 6. 


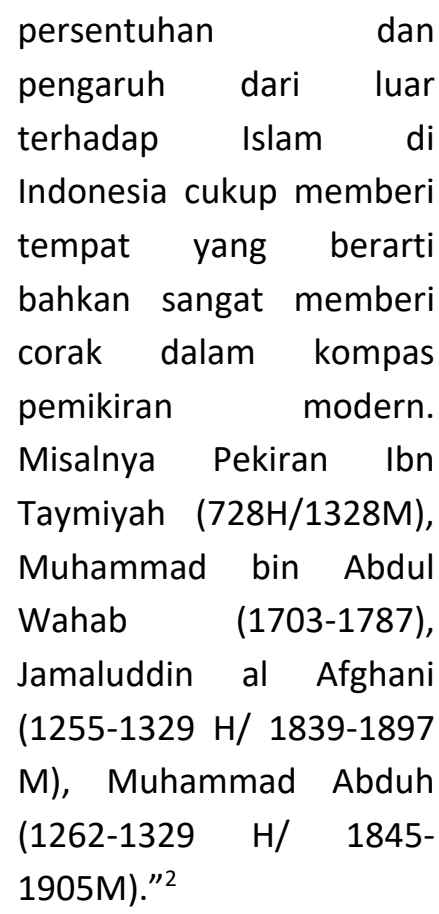

Pemikiran-pemikiran inilah yang sangat mewarnai perjuangan umat Islam dari awal abad 19-20, yang merupakan kebangkitan dan permurnian ajaran Islam yang mempersatukan umat Islam dalam wadah Pan Islamisme yang selalu dikobar-kobarkan dalam melawan kolonialisme dan penjajah. ${ }^{3}$

Demi untuk menyebarkan Ilmunya, para ulama yang kembali dari tanah arab mendirikan pesantren pesantren dan menghasil para santri yang menjadi benteng dan tombak dalam membendung serangan serta gerakan penjajah yang ada di Indonesia sejak awal masuknya penjajah, ${ }^{4}$ dan

\footnotetext{
${ }^{2}$ Abdul Sani, Lintasan Sejarah Pemikiran Perkembangan Modern dalam Islam ( Jakarta: PT. Raja Grafindo, 1998), hlm. 186.

${ }^{3}$ Sani, Lintasan Pemikiran, hlm. 186.

4 Baca, Ahmad Mansur Surya Negara, Menemukan Sejarah: Wacana Pergerakan
}

gerakan Perjuanga santri ini lebih tampak dan jelas sebelum adanya gerakan-gerakan lain. Sebagai contoh dapat kita lihat perang Cirebon (18021806), perang Diponegoro (18251830), perang Padri (1821-1838), perang Aceh (1873-1908). ${ }^{5}$ Semua perjuangan ini dilakukan oleh para santri dan ulama, dan penjajah sering menyebutnya dengan perang sabil.

Sebelum tampak dengan jelas pengaruh Mesir terhadap Perjuangan bangsa Indonesia dalam mencapai kemerdekaan, Makkah telah banyak memciptkan ulama-ulama yang berasal dari Indonesia, seperti Syaikh Ahmad Khatib, Syaikh Thaher Djalaluddin, Syaikh Muhammad Djamil Djambek, Syaikh Ahmad Soekarti ${ }^{6}$ dan lain-lain. Dengan adanya gerakan pemabaharuan yang berlansung di Mesir, maka minat dari para pelajar Indonesia semakin tinggi untuk menimba ilmu di sana. Disokong dengan seruan dari para tokoh-tokoh dan ulama pada Waktu itu untuk mengajak Umat Islam Indonesia khusunya ulama untuk melakukan pembaharuhan serta dorongan untuk memperoleh kemerdekaan dan terlepas dari penjajahan. Melalui proses pendidikan dan pembaharuan pemikiran maka lahirlah tokoh-tokoh dalam kalangan umat Islam Indonesia dalam membangkitkan semangat perjuangan, diantaranya K. H. Ahmad Dahlan ( 1868-1923), Syaikh Ahmad

Islam Indonesia” (Bandung : Mizan, cet. Ke-3, 1996), hlm. 240.

${ }^{5}$ Ibid.

${ }^{6}$ Ibid, hlm. 7. 
Soekarti (1872-1943) dan Haji Rasuli $(1879-1945)^{7}$. Dengan kehadiran para cendikiawan Muslim yang menimba Ilmu pendidikan di Mekkah dan di Mesir maka muncul ide-ide dan gerakan pembaharuan dalam perjuangan bangsa Indonesia, secara khusus dalam sistem pendidikannya. Berdirinya al Irsyad, Muhammadiyah, Persatuan Islam, Jami'at al Khair, yang merubah sistem pendidikan halaqah menjadi kelas, serta memasukkan pelajaran umum dalam pendidikan agama, dan tidak sekedar berkutat dalam pendidikan bahasa Arab dan kitab kuning serta fiqh Syafi'i semata, sehingga lapangan ijtihadpun terbuka kembali dengan diberangusnya taklid, takhayul dan khurafat dalam pendidikan tradisional.

\section{B. Pengaruh Pan Islamisme Terhadap Islam di Indonesia dan gerakan Berbasis Agama}

\section{Perang Paderi}

Paderi adalah sebutan untuk kelompok pembaharuan yang modernis yang ada di Minangkabau, kelompok ini bertujuan untuk mengubah pengaruh negatif kaum tua, adatistiadat yang tidak sesuai dengan syariat, dan juga menentang penjajahan Inggris yang ada pada waktu itu sebelum datangnya belanda pada tahun 1821 M ke Minangkabau ${ }^{8}$. Pengaruh pembaharuan ini dikenal juga dengan pemurnian akidah Islam yang dipelopori oleh Haji Miskin, Haji

${ }^{7} \mathrm{Ibid}, \mathrm{hlm} .6$.

${ }^{8}$ Sani, Lintas Sejarah, hlm. 188-189.
Sumanik, Haji Piobang yang pulang ke ranah Minang tahun $1803 \mathrm{M}$, dimana pada saat Itu gerakan pemurnian akidah Islam Muhammad bin Abdul Wahab sedang berkembang.

Perjuangan kaum paderi ini tidak berjalan begitu mulus, dikarenakan kaum tua dan kaum adat mendapatkan sokongan bantuan dari penjajah, akan tetapi perjuangan kaum paderi tidak bisa di bendung. Hal ini sangat membikin kaum adat dan kaum penjajah pusing, hadirnya para pejuang yang tidak kenal kompromi dengan penjajah diantara nya tuanku Nan Renceh yang terkenal pemberani dalam mengahadapi penjajah. Di samping dibentuknya dewan paderi yang terorganisir dengan sebutan Harimau nan Salapan, Tuankun Nan Renceh (Kamang), Tuanku Lubuk Aur (Candung), Tuanku Berapi (candung), Tuanku Ladang Lawas (Banuhampu), Tuanku Padang Luar, Tuanku Galung ( Sungai Puar), Tuanku Biaro dan Tuanku Kapau. ${ }^{9}$ Tidak ketinggalan tokoh-tokoh pejuang lainnya seperti Syaikh jalaluddin, Abdurrauf, Habib Abdurrahman, Tuanku Tambusai, Tuanku Di Tampang, Tuanku Damasiang, Tuanku Nan Cerdik, Tuanku Imam Bonjol. ${ }^{10}$

Hadirnya ide pemersatu yang dikemukankan oleh Imam Bonjol sehingga kaum adat dan kaum Paderi bisa bersatu dalam menentang penjajah dengan tetap mengakui sebagian adat

\footnotetext{
${ }^{9}$ Ibid, hlm. 189.

${ }^{10} \mathrm{Ibid}$, hlm. 191.
} 
yang tidak bertenatangan dengan sayriat Islam.

\section{Kaum Muda}

Kaum muda adalah sebuah sebuatan sebagai estafet perjuangan kaum Paderi, yang mana masih mengacu kepada pemurnian ajaran Islam dan menentang adat kaum tua. Istilah gerakan kaum muda ini awalnya dikenal di Minangkabau, namun pada akhirnya menyebar dan dikenal diberbagai wilayah sebagai ciri kelompok modern dalam mengamalkan pemurnian ajaran Islam. ${ }^{11}$ Gerakan kaum muda ini sangat kental dan gigih dalam memberangus bid'ah, khurafat, memuliakan wali secara berlebihan, serta memuliakan kuburan, menyabung ayam, minum arak, termasuk juga paham keagamaan primitivisme, Hinduisme, maupun Budhisme. ${ }^{12}$

Gerakan pemurnian ini dilakukan dengan cara memanfaatkan media tulisan, ceramah agama, mendirikan pondok-pondok pesantren ${ }^{13}$ dengan metode-metode yang lebih terbuka dan menggunakan bahasa asing Arab dan Belanda.

Gerakan ini, disamping sangat bertentangan dengan paham kaum tua (tradisoanal), dan sering mendapat tekanan, bahkan mengkafirkan gerakan pembahruan seperti ini. Dilain sisi juga membuat para penjajah khususnya Belanda pada waktu itu yang telah

\footnotetext{
${ }^{11}$ Ibid, hlm. 192-193.

${ }^{12}$ Sani, Lintas Sejarah, hlm. 193.

${ }^{13}$ Di antara pesantren itu adalah Pesantren Sumatera Thawalib.
}

masuk kewilayah Minang kocar-kacir dengan gerakan muda yang teroganisir seperti ini. Adapun tokoh-tokoh muda ini adalah Syaikh Muhammad Abdullah Ahmad (1878-1933), Syaikh Abdul Karim Amrullah (1879-1945), Syaikh Muhammad Djamil Djambek (1860-1947), Syaikh Muhammad Ibrahim Musa Parabek (1884-1963) dan lain-lain.

\section{Jami'at al Khair dan al Irsyad}

Di samping terjadinya gerakan pembaharuan di Minang Kabau oleh kaum muda, di Jawa, khususnya Jakarta, yang pertama kali menggaungkan pembaharuan serta pemurnian terhadap ajaran Islam adalah Jami'at al Khair, yang didirikan pada 17 juli $1905 \mathrm{M}^{14}$. Diantara pendirinya Sayyid Muhammad al Fakhir ibn al Mansyur, Sayyid Idrus, Sayyid Sjehan dan Sayyid Sjihab.

Jami'at al Khair lebih memusatkan perhatiannya kepada dunia pendidikan dengan mendirikan sekolah-sekolah, demi untuk membendung pengaruh penjajah dalam dunia pendidikan, yang lebih bersifat kristenisasi. Untuk menyaingi sekolahsekolah didikan Belanda, Jami'at Khair mendirikan sekolah berbentuk pesantren sekolah, dengan tetap mempertahankan pendidikan agama dan menambahkan pelajaran umum. Arah dan tujuan yang diharapkan dari pembaharuan dalam pendidikan ini adalah untuk membuka ruang yang lebih luas dalam pendidikan, tidak

${ }^{14}$ Sani, Lintas Sejarah, hlm. 195. 
hanya sebatas mengurus kitab kuning yang dihafal di luar kepala, tahlilan dan tarekat. ${ }^{15}$

Dalam tubuh Jami'at al Khair sendiri ada perselisihan yang terjadi antara golongan sayid yang selalu ingin dihormati dan tidak mau menikah kecuali dengan golongan sayid sendiri, ${ }^{16}$ serta keharusan mencium tangan kepada kelompok sayid. Fenomena seperti ini tidak diterima oleh tokoh moderat Jami'at al Khair, tidak menerima adanya perbedaan strata yang melanggar prinsip persamaan yang ada dalam agama Islam. Akibat dari adanya perbedaan dalam tubuh organisasi sehingga menjadi lemah, maka berdirilah al Irsyad (Jami' at al Islamiyah wa Irsyad al A'rabiyah) yang didirikan oleh para pedagang dan tokoh-tokoh bukan keturunan arab atau sayyid saja, diantaranya adalah Syaikh Umar Manggus, Shaleh bin Ubaid Abdad, Salom bin Umar Balfas, Abdullah Harrah, dan Umar bin Shaleh bin Nahdi pada tahun 1913.

Ahmad Sokarti ${ }^{17}$ adalah salah satu tokoh yang berpengaruh dalam organisasi ini yang sangat banyak membantu dalam modernisasi pendidikan di Indonesia. tidak hanya sampai disini, para pelajar dari al 197.

15 Baca Sani, Lintas Sejarah, hlm. 195-

${ }^{16}$ Warga Indonesia keturunan Arab.

${ }^{17}$ Seorang ulama kelahiran Sudan (18721943), yang mengembara menimba ilmu ke Mekkah dan akhirnya sampai dan menetap di Indonesia, ide-ide pembaharuannya juga seperti ide-ide pembaharuan yang dibawakan oleh Muhammad Abduh dan Rasyid Ridha.
Irsyad sendiri banyak yang di kirim ke Timur Tengah khususnya Mesir. Al Irsyad juga menyuarakan emansipasi sosial $^{18}$ sehingga tidak ada lagi pengkultusan terhadap individu atau kelompok. Melalui gerakan emansipasi sosial ini berdampak buruk terhadap pengaruh Belanda dan politiknya yang akan menciptakan keharmonisan dikalangan bangsa Indonesia khususnya umat muslim, dan al Irsyad tidak sekedar bergerak dalam bidang pendidikan tapi juga bergerak di dalam politik $^{19}$.

\section{Muhammadiyah}

Organisasi ini didirikan pada 18 November 1912 M, oleh Muhammad Darwis dan lebih dikenal dengan K.H Ahmad Dahlan, lahir di Yogyakarta tahun $1868 \mathrm{M}$ dengan ayahnya yang bernama K.H. Abu Bakar seorang khatib Masjid Agung kesultanan Yogyakarta.

Tahun 1890 K.H. Ahmad Dahlan berangkat ke Makkah untuk naik haji dan pernah belajar dengan Syaikh Ahmad Khatib al Minagkabawi ${ }^{20}$, dan beliau juga pernah berguru dengan Syaikh Djamil Djambek, ${ }^{21}$ yang memiliki reputasi dan berwawasan modern pada waktu itu. ${ }^{22}$ Sekembalinya dari Mekkah K.H

18 Penghapusan strata dalam masyarkat dan persamaan derajat.

19 Baca Sani, Lintas Sejarah, hlm 199. 201.

20 Seorang ulama berasal dari Minang yang menjadi imam Masjid al Haram pada waktu itu.

${ }^{21}$ Salah seorang ulama dari Bukittinggi,

22 Sani, Lintas Sejarah, hlm. 202. 
Ahmad Dahlan banyak melakukan ideide perubahan, diantaranya adalah membetulkan arah kiblat yang salah, walaupun banyak mendapatkan pertentangan dari kalangan tradisionalis. Disamping itu, ide pembaharuan yang digalakkan oleh K.H. Ahmad Dahlan dengan mendirikan orgasasi Muhammadiyah adalah untuk memberikan pembaharuan dalam dunia pendidikan, pemurnian ajaran Islam serta bemberangus bid'ah, takhayul, khurafat, memberantas kemiskinan dengan mendirikan badan wakaf dan zakat, meningkatkan taraf kehidupan manusia dengan membangun perekonomian dengan badan amal usahanya. Cita cita pembaharuan ini juga tidak lepas dari pengaruh pemurnian akidah yang pernah dilakukan oleh Ibn Taymiyah , Muhammad bin Abdul Wahab, serta Pan Islamisme yang dibawa oleh Jamaluddin al Afghani, Muhammad Abduh, dan lain-lain yang mengusung persatuan, pembaharuan dan kemerdekaan. $^{23}$

\section{Sarekat Dagang Islam}

Menurut Ahmad Mansur Suryanegara, SDI didirikan oleh $\mathrm{H}$. Samanhudi paa tanggal 16 Oktober 1905. Dalam gerakan awalnya terjadi kerjasama yang baik antara Islam dan para pedagang Cina, bahkan banyak yang menjadi Muslim. Namun melihat persatuan yang terjadi antara umat Islam dan Cina Belanda merasa ini

${ }^{23}$ Sani, Lintas Sejarah,hlm. 206. sebagai ancaman yang bisa menimbulkan persatuan antara umat Islam khususnya dan dengan Cina, yang merupakan ancaman bagi politik Belanda. Bukan hanya sampai di situ saja, SDI juga telah berhasil menyatukan antara kaum priayi dan masyarakat awam. Melihat fenomena ini Belanda membikin propaganda dan fitnah, yang pada akhirnya menimbulkan gerakan anti Cina, sehingga timbul peperangan di Solo antara SDI dan dibantu oleh tentara mangkunegaran tahun 1911, dan sebaliknya Cina menjalin hubungan erat dengan Belanda. ${ }^{24}$

Menurut Dr. Karim SDI didirikan di Jakarta 5 April 1909 yang diprakarsai oleh seorang jurnalis Solo R.M Tirtoadisurjo dan diketuai oleh Syekh Achmad bin Abdurrahman Badjenet, salah seorang saudagar kaya dari Bogor ${ }^{25}$. Berdirinya organisasi ini setalah berdirinya boedi Oetomo yang diprakarsai dan dia anggotakan mulai dari kaum priayi rendah, yang mendapat pesimistis dari masyarakat bawah. Tujuan dari organisasi ini adalah untuk menunjukan sebuah perjuangan yang benar-benar mendukung masyarakat kecil, sehingga rakyat tidak hanya sebagai korban dan budak ekonomi akan tetapi bisa sebagai pelaku ekonomi yang orientasinya seperti yang disebutkan oleh Dr. Karim.

24 Baca Surya Negara, Menemukan Sejarah, hlm. 244-248.

${ }^{25}$ Baca, Karim, Islam dan Kemerdekaan, hlm. 21 . 


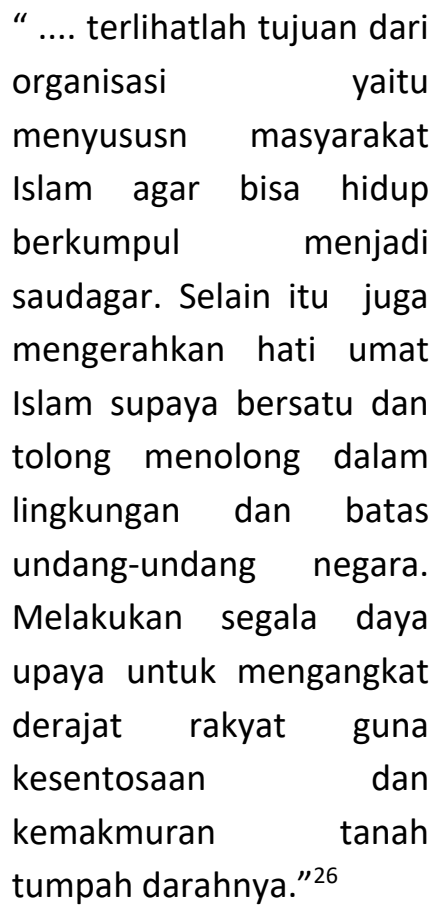

Tidak begitu banyak tampak saudagar-saudagar Islam yang menjadi pelaku ekonomi sebelum terbentuknya SDI ini, dimana sebelumnya perekonomian banyak dimonopoli oleh kalangan Tionghoa, Cina dan non pribumi $^{27}$ yang berani membayar pajak banyak kepada penjajah demi untuk meraup keuntungan yang banyak. Dibalik itu juga Belanda bisa memanfaatkan Tionghoa sembagai sumber Informasi dari kegiatan umat Islam atau bisa kita sebut sebagai matamata Belanda agar mendapatkan perlindungan dan eksistensi dari penjajah. $^{28}$

Pada tanggal 11 November 1911 SDI pun mengalami perubahan

${ }^{26}$ Baca, Karim, Islam dan Kemerdekaan, hlm. 24 .

${ }^{27}$ Sani, Lintasan Sejarah, hlm. 209

${ }^{28}$ Baca, Karim, Islam dan Kemerdekaan, hlm. 23. menjadi SI (Syarekat Islam), yang diprakarsai oleh H.O.S Tjokroaminoto (1883-1934). SDI yang pada awlnya bergerak dalam memperjuangakan hak umat Islam dan kaum awam dalam perekonomian dan peedagangan, dengan hadirnya SI pergerakan sudah merambas kedalam dunia politik. Gerakan yang dilakukan oleh SI ini merupakan respon dari ketidaksukaan terhadap pemerintah Belanda yang merupakan lintah darat yang suka memakan darah rakyat, juga demi mendirikan negara Islam yang terlepas dari penjajah. H.O.S Tjokroaminoto menyebutkan sebagaimana yang dikutip oleh Abdul Sani dari buku Syafii Ma'arif dalam buku studi tentang percaturan dalam konstituante Islam dan masalah kenegaraan.

"... tidak boleh tidak kita sebagai kaum muslimin mesti mempunyai kemerdekaan umat atau mempunyai kemerdekaan kebangsaan yang mesti berkuasa atas negeri tumpah darah kita sendiri." ${ }^{29}$

Boleh kita katakan bahwasanya SI merupakan organisasi politik Islam modern yang muncul pada awal abad 20, yang memiliki indikasi Pan Islamisme yang dimiliki oleh Jamaluddin al Afghani. adapun tokoh dan penggerakknya banyak dianggotai oleh masyarakat petani dan awam,

\footnotetext{
${ }^{29}$ Baca Sani, Lintasan Sejarah, hlm. 208-
} 214 . 
berbeda dengan Budi Utomo yang dianggotai oleh kaum priayi. Diantara tokoh pergerakan SI adalah H. Agoes Salim dan Abdoel Muis. ${ }^{30}$

Melihat pergrakan politik SI yang begitu banyak mendapatkan dukungan, maka pemerintah Belanda mencoba untuk mengusik dan merusak perjuangan dengan memasukan paham Marxisme ke dalam tubuh SI, melalui sebuah organisasi ISDV / Organisasi Sosial Deokrasi Hindia Belanda pada tahun 1914 yang berubah menjadi Partai Komunis Indonesi (PKI) pada tanggal 23 Mei 1920, dengan mengutus tokoh-tokohnya Semaun dan Alimin. Masuknya paham Marxisme ini, ide dan cita - cita untuk meperoleh kemerdekaan dan mendirikan negara yang berbasis Islam hanya menjadi simbol nasional karena banyaknya anggota SI yang keluar karena paham Marxisme yang msuk kedalam tubuh SI.

Mundurnya gerakan perjuangan SI, maka munculah sebuah gerakan politik perjuangan kemerdekaan yang kurang diwarnai oleh jiwa keIslaman. Sani menyebutkan

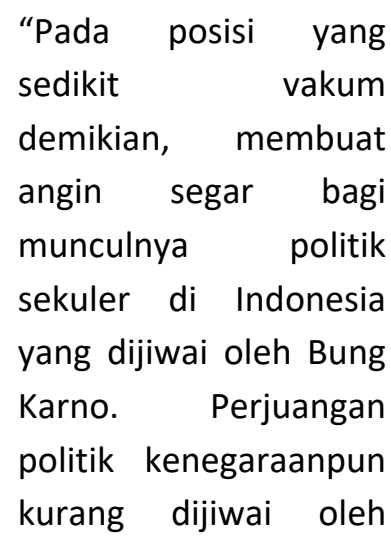

${ }^{30}$ Ibid, hlm. 212. semangat ke

Islaman." ${ }^{31}$

Akan tetapi gerakan perjuangan oleh tokoh-tokoh SI tetap berlanjut hinggga Indonesia mencapai kemerdekaan. Seperti berdirinya parta Islam Indonesia tahun 1938 oleh Dr. Sukiman Wirdjosandjojo, Muhammad Nastir, Kahar Muzakkir. Partai Syarikat Islam Indonesia oleh Abisukmo Tjoksujoso. Sedangkan pada masa kedudukan Jepang diwarnai dengan terbentuknya Masyumi pada tahun 1945 .

\section{Persatuan Islam ( Persis)}

Merespon dari realita yang ada pergolakan, dan pertikaian yang terjadi pada al Irsyad / Jami'at al Khair serta masuknya komunisme kedalam tubuh SI, dan berkembangnya pemikiran pembaharuan dalam Islam, maka berdidirlah PERSIS yang dipelopori oleh H. Zam zam, dan H. Muhammad Junus di Bandung pada tahun 1920. ${ }^{32}$

Tokoh pergerakan PERSIS yang paling berpegaruh diantaranya adalah Ahmad Hasan yang lebih bergerak dalam pemurnian akidah Islam $^{33}$, karena pemikirannya sangat dipengaruhi oleh paham pembaharuan yang dibawakan oleh Muhammad bin Abdul Wahab. Selanjutnya adalah Muhammad Nastir, seorang tokoh Pembaharu yang lebih bergerak pada dunia pendidikan yang berorientasi

\footnotetext{
${ }^{31}$ Sani, Lintasan Sejarah, hlm. 212.

${ }^{32} \mathrm{Ibid}$, hlm. 222.

${ }^{33}$ Ibid, hlm. 224.
} 
kepada semangat dan dinamika perubahan zaman. Meskipun Nastir bukanlah seorang anak didikan pesantren akan tetapi dia memiliki guru dari kalangan ulama yang merupakan tokoh-tokoh pembaharu yang banyak memberikan sumbangsih pemikiran terhadapnya, diantaranya adalah Tuanku Mudo Amin seorang sahabat dari kiyai Haji Rasuli, dan H. Abdullah Ahmad. ${ }^{34}$

\section{Nahdhatul Ulama}

Sani menyebutkan dari bukunya Deliar Noer "Gerakan Modern Islam Indonesia"

$$
\begin{aligned}
& \text { "Bahwa berdirinya NU } \\
& \text { selain dilatar belakangi } \\
& \text { kasus penggantian } \\
& \text { kekuasaan di Hijaz juga } \\
& \text { karena adanya } \\
& \text { pembongkaran tempat- } \\
& \text { tempat suci seperti } \\
& \text { kuburan Nabi yang tidak } \\
& \text { diberi kubah dan } \\
& \text { diratakan dengan tanah. } \\
& \text { Padahal tempat tersebut } \\
& \text { merupakan tempat suci } \\
& \text { yang selalu diziarahi } \\
& \text { sebagian besar umat } \\
& \text { Islam Indonesia. } \\
& \text { kesemuanya itu } \\
& \text { dilakukan oleh gerakan } \\
& \text { wahabi bersama } \\
& \text { kerajaan ibn Saud di } \\
& \text { Mekkah. } \\
& \text { Selain } \\
& \text { itu, } \\
& \text { nampaknyapertentangan } \\
& \text { antara Kaum muda dan }
\end{aligned}
$$

\footnotetext{
${ }^{34}$ Sani, Lintasan Sejarah,hlm. 226.
}

$\begin{array}{lrr}\text { Kaum } & \text { Tua, yang } \\ \text { membuat } & \text { Kaum } & \text { Tua } \\ \text { terdesak } & \text { dikalangan } \\ \text { umat Islam } & \text { lalu } \\ \text { kemudian } & \text { mendorong } \\ \text { para ulama } & \text { kaum Tua } \\ \text { berinisiatif menggalang } & \text { man } \\ \text { kekuatan masa } & \text { untuk } \\ \text { mempertahankan } & \\ \text { statusquo } & \\ \text { ketradisionalan } & \text { mereka } \\ \text { terhadap ran } & \text { gagasan } \\ \text { pembaharuan } & \text { dari } \\ \text { kelompok } & \text { kaum } \\ \text { muda." }{ }^{35} & \end{array}$

Menaggapi statement ini, perlu kita pahami bahwasanya K.H Hasyim Asy'ari adalah sahabat dekat K.H Ahmad Dahlan, satu perjuangan dan senasib sepenanggungan. Dalam wajah pergerakan dalam memperjuangakan kemerdekaan hampir memiliki landsan dan orientasi yang sama. K.H Ahmad Dahlan hadir dengan modernisasi sistem pendidikannya, dan begitu juga K.H Hasyim Asya'ri hadir dengan membawa perkumpulan Nahdhatul Ulama ini untuk mengembangkan agama Islam melalui tabligh-tabligh melalui pendidikan agar umat Islam menyadari dan sadar akan kewajibannya terhadap agama bangsa dan tanah air. ${ }^{36}$ Jadi antara

35 Ibid, hlm. 216.

${ }^{36}$ M. Abdul Karim, Sejarah Pemikiran dan Peradaban Islam, Yogyakarta: Bagaskara, 2012, hlm. 338. 
Muhammadiyah dan NU memiliki peran yang saling mengisi dalam peranannya memperjuangkan kemerdekaan Indonesia ini. Meskipun pada hari ini antara NU yang ada sekarang dengan $\mathrm{Nu}$ yang didirikan oleh K.H Hasyim Asya'ri ada perbedaannya. ${ }^{37}$

NU sendiri didirikan di Surabaya 31 Januari 1926 M. Oleh K.H Hasyim Asy'ari sebagai tokoh pendiri. Diantara tokoh NU yang lain adalah K.H. Abdul Wahab Hasbullah yang lahir di Jombang maret 1888, K.H. Bisri, lahir di Jawa Tengah 1887. Walaupun NU berbeda dengan pembaharuan pergerakan yang lain namun memiliki peran penting juga dalam perjuangan kemerdekaan Indonesia, yang banyak bergerak dalam panggung perpolitikan Indonesia. bahkan berhasil mengalahkan kekuatan politik partai PKI. ${ }^{38}$

Masuknya $\mathrm{Nu}$ dalam pergerakan politik itu lebih dominan diprakarsai oleh K.H Abdul Wahab Hasbullah, dimana umat Islam juga harus memiliki parlement tersendiri. ${ }^{39}$ Umat Islam harus mempunyai kekuatan dalam politik, yang tidak hanya dominan dipegang oleh para tokoh-tokoh para tokoh nasionalis, Akan tetapi para ulama juga harus bisa ikut serta dalam percaturan perpolitikan, agar cita-cita kemerdekaan lebih cepat terwujud.

\footnotetext{
${ }^{37}$ Pemaparan Prof. Dr. M. Abdul Karim

${ }^{38} \mathrm{Ibid}, \mathrm{hlm} .217$.

${ }^{39}$ Baca, Karim, Sejarah Pemikiran, hlm.
} dalam kelas. $338=339$.
Pada masa kependudukan Jepang pergerakan NU dalam kancah politik selain dalam bidang pemerintahan juga membentuk unit meiliter bagi pemuda Islam dengan nama Hizbullah, yang bergerak dalam perjuangan cita-cita kemerdekaan dengan semboyannya “ Hidup mulia atau mati Syahid". ${ }^{40}$ Mendekati kemerdekaan Indonesia Aktiftas ulama NU juga terlihat dalam pembentukan rancangan ideologi negara dan perundang-undangannya yang memiliki Ideologi Islam dalam sidang BPUPKI 9 April 1945. Diantara tokoh tersebut adalah K.H Wachid Hasyim, dan K.H Masykur. Meskipun pada akhirnya pembentukan ideologi Islam terhadap negara bisa dibilang tidak gol, karena berhadapan dengan pandangn kelompok nasionalis dan non Islam, akan tetapi nilai-nilai ke Islaman serta perjuangannya tidak pernah pudar. ${ }^{41}$ Pergerakan politik umat Islam ini selalu berjalan dan menghasilkan wadah yang lebih besar dengan lahirnya MIAI yang kemudian menjadi Masyumi. ${ }^{42}$ Adanya ruh dan semangat yang ada dalam Islam dan Iman, membuat kaum Muslim lebih giat dan kuat untuk memperjuangkan kemerdekaan Indonesia. ${ }^{43}$

\section{MIAI}

$$
\begin{aligned}
& \text { Dr. Karim memaparkan } \\
& \text { “ Sebagai } \\
& \text { yang }
\end{aligned}
$$

\footnotetext{
${ }^{40}$ Ibid, hlm. 220.

${ }^{41}$ Baca, Ibid, hlm.221.

${ }^{42}$ Sani, Lintasan Sejarah, hlm. 222.

${ }^{43}$ Baca, Karim, Islam dan Kemerdekaan, hlm. 40.
} 


tercapainya kemerdekaan
ialah kekuatan organisasi
dan kekuatan partai.
Menjelang detik-detik
kemerdekaan Kaum Muslim
telah memprakarsai untuk
mengikat kekuatan-
kekuatan organisasi partai
menjadi satu ikatan yang
tergabung dalam MIAl (
Majlis Islam A'la Indonesia).
organisasi ini didirikan
tanggal 21 September 1937
M yang didukung oleh
segenap organisasi Islam di
Indonesia." ${ }^{44}$

Pada awalnya gerakan ini diprakarsai oleh Muhammadiyah dan NU, sebagai bentuk langkah pembaharuan $^{45}$. Hadirnya gerakan politik persatuan ini $^{46}$, sehingga seluruh pergerakan dan kekgiatan menjadi terpusat, fenomena ini sangat menggetarkan Belanda. Disaat pengaruh partai dan kelompok Islam lain mengalami kemunduran, akan tetapi pengaruh MIAI dikalangan umat $49-40$

${ }^{44}$ Karim, Islam dan Kemerdekaan, hlm.

46 Sebagai mana yang disebutkan oleh Harry J. Benda dalam bukunya Bulan Sabit dan Matahari Terbit Islam Indonesia Pada Masa pendudukan Jepang, Terjemahan Daniel Dhakidae (Bandung: Pustaka Jaya cet. Ke-2 , 1985), hlm. 119 “.. sekali lagi perlawanan terhadap kekuatan luar menyempitkan jurang perbedaan antara kaum reformis dan ortodoks samapi ketitik dimana Muhammadiyah dan NU bersama-sama mampu mensponsori diciptakannya suatu federasi Islam yang baru. MIAI.”
Islam sebagai wadah gerakan dan politik yang masih bisa menyatukan suara perjuangan umat Islam untuk mencapai kemerdekaan hingga masa kependudukan Jepang di Indonesia.

Melihat pengaruh MIAI yang begitu besar Jepang berusaha untuk memadamkan pengaruhnya dari kalangan umat Islam, bahkan menghilangkan nama MIAI itu sendiri dengan membentuk Majelis Syura Muslimin Indonesia ${ }^{47}$ pada tahun 1944 dengan mengangkat Hasyim Asy'ari sebagai ketuanya. Tujuan dari pembentukan Masyumi ini oleh jepang untuk menjauhkan para pimpinannya dari kegiatan politik dan dapat mengontrolnya. ${ }^{48}$

Berniat untuk memadamkan pengaruh Islam dalam perpolitikan, dengan berdirinya Masyumi terbentuklah pasukan Hizbullah sebagai hasil dari rapat akbar umat Islam di taman Raden Saleh Jakarta 1314 September 1944. Tipu daya Jepang untuk memdekati dan mempengaruhi umat Islam ternyata menghasilkan sebuah pemberontakan oleh tentara PETA yang dipimpin oleh Supriyadi 14 Februari 1945. Dilatar belakangi oleh sikap semena-mena Jepang serta menderitaan rakyat yang semakin menjadi-jadi dan janji kemerdekaan yang belum terealisasikan. ${ }^{49}$ Pemberontakan yang dilakukan tidak hanya oleh tentara PETA ini, bahkan

47 Surya Negara, Menemukan Sejarah, hlm. 262-263.

\footnotetext{
${ }^{48}$ Ibid.

${ }^{49}$ Ibid, hlm. 265.
} 
oleh kaum santri mendapatkan dukungan dari kalangan politikus, seperti Bung Karno dan Bung Hatta, tidak pernah ketinggalan dukungan dari para ulama. ${ }^{50}$

\section{Gerakan Nasionalis \\ 1. Boedi Utomo}

Gerakan ini dilatar belakangi atas dasar semangat kebangsaan yang diprakarsai oleh Mas Ngebehi Soediro Husodo seorang dokter yang bersal dari Yogyakarta. Dia mulai mengembangkan pemikirannya pada tahun 1906-1907 melalui badan wakaf untuk memberikan beasiswa kepada pelajar-pelajar Indonesia yang ingin melanjutkan studinya. Termasuk pelajar dari kalangan non priayi yang sebenarnya mendapatkan tantangan dari kalangan priayi kelas atas yang memiliki hubungan dekat dengan Belanda, yang tidak menginginkan kaum awam dan rakyat biasa memperoleh pendidikan yang lebih tinggi. ${ }^{51}$ Namun ide gagasan ini mendapat dukungan dari kalangan terpelajar lainnya seperti Raden R. Soetomo, Raden Goenawan Mangoenkoesomo.

Hadirnya dukungan terhadap ide Wahidin ini maka terbentuklah sebuah organisasi Boedi Utomo pada tanggal 20 Mei 1908, dengan tujuan membina suatu perkumpulan yang bisa menggalang bangkitnya bangsa

${ }^{50} \mathrm{Ibid}$, hlm. 266. 19-20.
Indonesia. ${ }^{52}$ Mayoritas dari anggotanya adalah dari kalangan priayi. ${ }^{53}$

Melihat dari peranannya, bahwasanya untuk gerakan perjuanan kemerdekaan Indonesia lebih dominan dan diprakrasai terlebih dahulu oleh SDI yang berasaskan kepada Islam sebagai gerakannya. Gerakan SDI ini banyak mengahsilkan tokoh-tokoh nasional yang memiliki jiwa ke Islaman yang kuat serta nasioanlisme, yang sangat besar pengaruhnya terhadap kemerdekaan Indonesia. Namun pada hari ini, alasan mengapa hari Kebangkitan Nasional diperingati pada hari lahirnya Boedi Utomo dan bukan kepada hari lahirnya SDI, alasan itu kembali kepada ruh nasionalisme antara kalangan tokoh Inonesia yang terlepas dari asas atau embel-embel golongan. Artinya, gerakan ini murni gerakan nasional dan perjuangan bangsa indonesia terlepas dari kepentingan kelompok. Tokoh-tokoh yang ada didalam organisasi ini terangkum dari semua kalangan, baik itu ulama ${ }^{54}$ dan tokoh pergerakan yang nasionalis semata. Walaupun kita menyadari, yang menyalakan dan mengingatkan rakyat Indonesia akan pentingnya kemerdekaan adalah Islam dan umat Islam sendiri, sbeleum hadirnya tokoh-tokoh nasional dalam

52 Ibid.

53 Suryanegara menjelaskan dalam bukunya Mencari Sejarah Wacana Pergerakan Islam di Indonesia, menjelaskan bahwa K.H. Ahmad Dahlan sering memberikan pengajian kepada anggota Budi Utomo yang beranggotakan pangreh praja dan guru-guru.... hlm. 247.

${ }^{54}$ Baca, Islam dan Kemerdekaan, hlm. 38. 
melawan hegemoni penjajah dan perjuangan kemerdekaan.

\section{Sumpah Pemuda}

Gerakan sumpah pemuda ini didasari atas kesadaran perjuangan bersama dengan semangat nasionalisme yang tinggi untuk menyatukan perjuangan yang sebelumnya masih bersifat kedaerahan, seperti Jong Java, Jong Sumatera, Jong Ambon. Semangat persatuan itupun diwujudkan dalam sebuah konggres pemuda yang terlaksana pada tanggal 28 Oktober 1928 yang terkenal dengan sumpah pemuda. Hasil dari konggres ini melahirkan semangat Nasionalisme dengan Slogannya “ pemuda-pemuda Indonesia mengakui bertanah air satu, tanah air Indonesia, berbangsa satu, bangsa Indonesia,dan berbahsa satu bahsa Indonesia. ${ }^{55}$

Menurut Dr. Karim sumpah pemuda merupakan perwujudan dari gerakan nasionalisme Boedi Utomo, yang merupakan bentuk bagi kebangkitan nasional. Dalam pergerakannya banyak dipengaruhi oleh para tokoh yang bergama Islam seperti Tirtoadisurjo, Dr. Wahidin, K.H. Ahmad Dahlan, Cipto Mangkusumo, Dr. Soetomo, H. Samanhudi, Tjokro Aminoto ${ }^{56}$, dan masih bnyak lagi yang lain.

\section{Bab II. Setelah Kemerdekaan}

${ }^{55}$ Baca, Karim, Islam dan Kemerdekaan, hlm. 36 38.
A. Usaha dalam mempertahankan kemerdekaan

\section{Jihad lewat peperangan}

Dalam

memanfaatkan

kesempatan politik, pada masa penjajahan Jepang Muhammadiyah berhasil membina organisasi militer Tentara Pembela Tanah Air (PETA) ${ }^{57}$ bersama NU pada tahun $1943^{58}$ yang dilatih oleh Jepang dengan ulama sebagai komandan batalyonnya, pada akhirnya kekuatan ini yang mendasari terbentuknya tentara nasional Indonesia TNI. Antar NU dan Muhammadiyah memiliki semboyan sendiri dalam perjuangannya, Muhammadiyah dengan Hubbul Awthan Iman, sedangkan NU, dengan Hidup mulia atau Mati Syahid. Kekuatan ini yang nantinya sangat gesit dan kuat dalam mempertahankan kemerdekaan Indonesia dari penjajah yang ingin menguasai Indonesia kembali. Dimana tampak dengan jelas peranan ulama dan kiyai yang berada pada garis depan perjuangan mempertahankan kemerdekaan dan kedaulatan bangsa Indonesia.

$\mathrm{NU}$, disaat pemerintah $\mathrm{Ri}$ raguragu dalam menentukan sikap terhadap kependudukan kembali para sekutu penjajah, NU mengeluarkan resolusi jihad pada tanggal 22 Oktober 1945 di Surabaya. ${ }^{59}$ Begitu juga pada muktamar umat Islam di yogyakarta 7 November 1945 Muhammadiyah ikut mengeluarkan resolusi jihad " 60

${ }^{57}$ Suryanegara, Menemukan, hlm. 221.

${ }^{58}$ Ibid, hlm. 230.

${ }^{59}$ Suryanegara, Menemukan,hlm. 231. 
miljoen Kaoem Moeslimin Indonesia siap berjihad perang dijalan Allah menentang tiap pendjadjahan".60 Begitu juga dengan politik. Dari hasil pertemuan ini membentuk partai Islam Masyumi, membina potensi pemuda Islam melalui gerakan Pemuda Islam Indonesia (GPII), mengorganisir militer dengan Membentuk Hizbullah, dan pasukan sabilillah yang merupakan barisan utama Tentara Keamanan Rakyat (TKR). ${ }^{61}$ Dengan adanya resolusi jihad ini timbulnya perang antara bangsa Indonesia dengan Inggris di Surabaya tanggal 10 November $1945 .^{62}$

Perang Sabil Ambarawa, tanggal

10 Muharram $1365 \mathrm{H}$, atau 14 Desember 1945. Pada peperangan ini dimana pengaruh dan peranan ulama, kiai laskar Hizbullah sangat tampak jelas dibarisan depan dalam melumpuhkan militer sekutu yang baru saja memenangkan Perang Dunia ke dua, Inggris. Kemenangan pasukan ini dipimpin oleh Kiai Mochlish dari Cilacap. ${ }^{63}$ Kemenangan di Ambarawa inilah yang menjadikan Soedirman diangkat menjadi Panglima besar Tentara Keamanan Rakyat ${ }^{64}$. Tidak hanya terjadi di Ambarawa saja, sebagaimana yang dipaparkan koran Kedaulatan Rakyat ${ }^{65}$ yang di rangkum oleh Suryanegara, penyerbuan ke

${ }^{60} \mathrm{Ibid}, \mathrm{hlm} .222$.

${ }^{61} \mathrm{Ibid}$, hlm. 295-296.

${ }^{62} \mathrm{Ibid}$,hlm. 268.

${ }^{63}$ Baca, Suryanegara, Menemukan, hlm. 300.

${ }^{64} \mathrm{Ibid}$, hlm. 306.

${ }_{65}$ Sebuah media yang diterbtkan oleh badan Usaha Penerbitan Nasional Indonesia.
Banyubiru oleh laskar Hizbullah yang dipimpin oleh Kiai Komar dan berhasil merebut benteng Williem. ${ }^{66}$

\section{Politik}

dalam kancah perpolitikan, para tokoh ulama mempunyai posisi penting dalam menentukan arah dan tujuan bangsa, sebagai mana apresiasi yang diberikan oleh Bung Hatta kepaa tokoh ulama seperti Ki Bagus Hadikusumo, Mr. Kasman Singodimodjo, dan K.H Wahid Hasyim bersama Bung Hatta serta Teuku Hasan yang melahirkan falsafah Pancasila dan UUD 1945. ${ }^{67}$ Kehadiran ulama dan peranannya serta rumusan asas negara yang dicetuskan oleh para tokoh - tokoh Islam ini telah membuka pintu kemerdekaan Indonesia, meskipun terjadi revisi terhadap asas negara ini setelah kemerdekaan. Namun dengan hadirnya asa negara ini, Indonesia mendapatkan angin segar sebagai salah satu syarat wajib dalam membentuk sebuah negara, yaitu falsafah negaa.

Menyonsong kemerdekaan Indonesia, dengan dibentuknya BPUPKI ( Badan Penyelidik Usaha Persiapan Kemerdekaan Indonesia) 29 April 1945, yang diketuai oleh Rr. Radjiman Wediodiningrat. Pada tanggal 29 Mei - 1 Juni 1945 diadakanlah rapat tentang untuk menentukan asas dasar negara, yang dihadiri oleh tokoh nasionalis Islam dan non Islam. Seperti Ki. Bagus, H. Hadikusumo, K.H.M. Mansur,

\footnotetext{
${ }^{66}$ Suryanegara, Menemukan, hlm. 302.

${ }^{67}$ Ibid, hlm. 268.
} 
Sukiman, K.H. Wachid Hasyim, Kahar Muzakkir, dan Agus Salim. ${ }^{68}$ Pada sidang pertama ini belumlah menghasilkan satu rumusan, dan pada pertemuan 22 Juni 1945 yang terdiri dari Panitia Sembilan Ir. Soekarno, Drs. Muhammad Hatta, A.A. Maramis, SH. , Abikusno Cokrosuyoso, Abdul Kahar Muzakir, H. Agus Salim, Ahmad Subardjo, SH. K.H Wachid Hasyim, dan Muhammad Yamin, pada hari ini kita kenal dengan Piagam Jakarta, yang berisikan rumusan Pancasila.

Rumusan terakhir dari Piagam Jakarta diatas, sebelum disahkan oleh PPKI dilakukan oleh K.H Wachid Hasyim (NU), Ki Bagus Hadikusumo (Muhammadiyah), Kasman Singodimedjo (Muhammadiyah), Mohammad Hatta dan Teuku Mohammad Hasan ( Wakil dari Sumatera). Hasil dari rumusan yang dilkukan oleh kelima tokoh diatas disahkan oleh PPKI tanggal 18 Agustus 1945 yang menjadi falsafah bangsa Indonesia. Pancasila. ${ }^{69}$ Dalam pemaparan Prof. Dr. M. Abdul karim dalam kelas, bahwasanya pada hari pengesahan K.H Wachid Hasyim tidak hadir. Pada hari ini, dimana tokoh yang beraliran Nasionalis lebih dominan dari pada tokoh ulama. Dari hasil pertemuan ke dua ini terjadilah pengurangan terhadap Piagam Jakarta yang sebelumnya telah dirumuskan. Pengurangan atau perubahan itu adalah

\footnotetext{
${ }^{68}$ Suryanegara, Menemukan, hlm.266.

69 Suryanegara, Menemukan,hlm. 266267.
}

pada sila pertama yang berbunyi “ Ketuhanan dengan kewajiban menjalankan syari'at Islam begi pemeluk-pemeluknya", yang berubah menjadi " ketuhanan yang maha Esa.

Perubahan terhadap asas sila pertama ini dikarenakan adanya sanggahan-sanggahan dari penganut agama lain, yang tidak setuju dengan adanya istilah ini yang berindikasi terhadap berdirnya negara Islam di indonesia, dengan begitu agama lain khususnya Kristen juga ingin mendirikan negara Kristen. Alasan diterimanya perubahan tersebut adalah dimana umat Islam pada waktu itu lebih mementingkan persatuan untuk terciptanya sebuah kemerdekan serta berdirinya negara Republik Indonesia. ${ }^{70}$ Pertimbangan lain, adapun rumusan diatas tidak bertentangan dengan ajaran Islam, dan tokoh kalangan Islam kalah suara dari tokoh nasionalis yang ada pada waktu itu.

Sebagaimana yang teah disebutkan di atas, hadirnya Masyumi sebagai gerakan politik dengan wajah baru dalam tubuh umat Islam sebagai sebuah hasil muktamar ulama di Yogyakarta tanggal 17 November 1945, atau bisa sebut dengan kelahiran partai Masyumi, yang merupakan pusat aspirasi politik umat Islam pasca kemerdekaan Indonesia yang didukung oleh semua kalangan, baik itu kaum tradisionalis, modernis nasionalis Islam dalam dan luar jawa. ${ }^{71}$ Prinsip pokok

\footnotetext{
hlm. 104

${ }^{70}$ Baca Karim, Kemerdekaan Indonesia,

${ }^{71}$ Sani, Lintasan Sejarah, hlm. 228.
} 
dari gerakan politik ini adalah untuk merealisasikan ajaran dan hukum Islam di dalam kehidupan perorangan, masyarakat dan negara Republik Indonesia, untuk mencapai ridha Ilahi. $^{72}$ Tujuan pendirian Masyumi yang berkomitmen dalam menjunjung tinggi ajaran Islam, memberikan hakhak kepada setiap individu untuk mendapatkan hak-haknya, dan menjalankan perintah agama sebagaimana mestinya ${ }^{73}$ serta keadilan sosial ekonomi dan politik. Akan tetapi dalam perjalanannya masing-masing golongan yang ada dalam tubuh Masyumi belum bisa sepenuh bersikap toleransi dan melepaskan kepentingan golongan dan kelompok, serta berbedanya paham antara kaum modernis dan tradisionalis dan ketimpangan dalam peranan. Dewan eksekutif yang mengurusi masalah politik banyak dipegang oleh kaum modernis, sedangkan untuk urusan keagamaan dipegang oleh Kiai, yang pada akhirnya menjadikan Masyumi lemah karena adanya perbedaan kepentingan. ${ }^{74}$

Satu persatu unsur dari Masyumi melepaskan diri dan kembali mendirikan parta Independen seperti Partai Syarikat Islam Indonesia ( PSII) pada tahun 1947. Begitu juga dengan NU yang merupakan salah satu tonggak utama dan meprakarsai partai

\footnotetext{
${ }^{72}$ Ibid.

${ }^{73}$ Baca, Ibid, hlm. 229.
}

${ }^{74}$ Ibid, hlm. 231. ini juga memisahkan diri pada tahun 1952 dan membentuk parta sendiri. ${ }^{75}$

Melihat dari dampak ini, dimana partai-partai di Indonesia khususnya Islam mengalami perkembangan yang sangat sulit, sehingga pada pemilihan umum 1955, tidak dapat bersaing dengan partai dan gerakan nasionalis, yang memaksa harus adanya kompromi dalam bidang politik, sehingga partaipartai Islam dalam meneruskan perjuangan untuk menegakkan Islam memlalui konstituante dan bergabung dalam pemerintahan. Akan tetapi pengaruh Islam kurang begitu besar dipusat, dan lebih dominan diperani oleh aliran partai nasionalis, bahkan komunis. Sistim demokrasi yang diterapkan oleh Soekarno pada waktu itu bayak mempengaruhi terhadap perkembangan politik dalam tubuh Islam, serta kebijakan-kebijakan yang dilakukannya banyak mendapat tantangan dari kalangan tokoh nasioanalis Islam, karena sering bertentangan dengan paham ke Islaman, tetapi ide dan gagasannya banyak di dukung oleh partai-partai nasional dan komunis. Adapun dari parta Islam sendiri banyak yang menolak. Bisa kita bilang bahwa pada tahun 1955-1965 disebut dengan zman Soekarno, karena banyak menghimpun kekuasaan negara ditangannya sendiri. Sehingga pada tahun 1965 Hatta mengundurkan diri, melihat pengunduran ini banyak mendapatkan pertentangan dari kalangan luar jawa,

${ }^{75}$ Ibid, hlm. 231-232. 
dan anti komunis ${ }^{76}$. Pada tahun 1960 Masyumi dibubarkan disamping banyak dari tokoh politik Masyumi yang tidak suka dengan keotoriteran Soekarno dalam memimpin, akan tetapi menyisakan politikus dari NU yang masih sering bersama dengan pemerintahan Soekarno.

Pecahnya Masyumi, sampai hari ini belum ada satu wadah yang benarbenar bisa menyatukan kembali umat Islam dan pergerakannya dalam satu wadah. Semuanya bergerak sendirisendiri meski arah dan tujuannya adalah membela dan menegakkan syariat Islam. Namun realita hingga hari ini kebanyakan dari semboyan untuk memperjuangkan Islam belum bisa menyatukan setiap kepentingan kelompok, dan belum tunduk untuk kepentingan Islam. Bahkan berdirinya partai-partai yang bersemboyankan Islam makin menjamur, sehingga suara umat Islam terpecah belah. Kehidupan umat Islam yang mayoritas di negara inipun ikut terombang ambing, disamping kementrian agama yang berada dalam badan pemerintahan belum bisa memberikan pengaruh besar terhadap persatuan umat Islam dan menyuarakan tentang Islam.

Akan tetapi yang tersisa dari pergerakan yang pernah ada dari perjuangan umat Islam dari dahulunya hingga hari ini adalah dunia pendidikan pesantren dan madrasah serta kegiatankegiatan sosial yang masih berlansung hingga hari ini. Hadiah kemerdekaan ini adalah buah dari perjuangan

${ }^{76}$ Boland, Pergumulan Islam, hlm. 91. pendahulu kita, dengan semangat jihad yang tertanam atas dasar keimanan yang kuat terhadap Allah Swt, yang mestinya kita jaga dan pertahankan.

\section{Gerakan Pemikiran}

Gelagat Islam dalam catur perpolitikan sangatlah menjadi perhatian utama bagi beberapa kalangan dan kepentingan politik, dan itu sangat dapat kita rasakan pada masa pemerintahan Orde Baru, dimana kegiatan umat Islam selalu dicurigai dan di mata-matai, sayangnya itu dilakukan oleh pemimpin yang berstatus memeluk agama Islam. Selama terkungkung dalam masa itu, tidak begitu tampak perubahan dan pergerakan umat Islam dalam perpolitikan. Gerakan yang tumbuh mekar pada masa ini adalah gerakan pembaharuan dalam pemikiran yang sering dibawakan oleh pemikiran perorangan dan sering mengundang kontroversial. Bisa kita katakan pada akhir abad 20 corak yang muncul dalam tubuh Islam Indonesia adalah perang pemikiran, dimana masuknya paham-paham baru yang terkadang tidak sesuai dengan kemurnian ajaran Islam. Diantaranya adalah Nurcholish Madjid, Abdurrahman Wahid, ${ }^{77}$ Syafi'i Ma'arif, Harun Nasution, Ulil Abshar dan lain-lain.

\section{Penutup}

Perjuangan pergerakan corak umat Islam di Indonesia lebih identik

77 Baca, Boland, Pergumulan Islam, hlm. 235-255. 
dengan perjuangan merebuat kemerdekaan dari penjajah dan memperthankannya, serta upaya penerapan dasar-dasar hukum Islam di Indonesia. usaha perjuangan pergerakan bangsa Indoneisa juga terilhami oleh pengaruh pergerakna dan perkemabangan pemikiran dari Timur Tengah, baik itu Mekkah dengan permunian ajaran Islamnya, Mesir, dan India, yang membawakan panji Pan Islamisme, untuk mempersatukan umat Islam dalam merebut kemerdekaan dan mengusir para penajah.

Perlawan umat Islam di Indonesia telah berawal sejak awal masuknya penjajah ke nusantara ini, dan perlawanan pun banyak terjadi dalam bentuk fisik yang sering memukul mundur dan membuat gentar para penjajah. Akhir abad ke 19 memasuki abad 20, dimana Belanda mencoba untuk memainkan politiknya dengan menerima Islam dan mendekati para ulama lalu melalukan tanam paksa agar umat Islam tidak terlalu ikut campur dalam urusan politik yang selama ini membuat penjajah pusing. Didalam dunia pendidikan belanda juga berusaha memasukkan pemahaman yang salah/ terhadap ajaran Islam, dengan menutup pintupintu ijtihad. Dari segi ekonomi penjajah juga memainkan cengkramannya sehingga rakyat makin menderita, dibantu oleh para saudagarsaudagar Cina yang ingin mendapatkan perlindungan dari Belanda. Prof. Karim menyebutkan ada beberapa faktor yang mendorong umat Islam dalam mencapai kemrdekaan, faktor idiologi, politik, ekonomi, Sosial dan budaya. ${ }^{78}$

Akan tetapi kenyataan, berbalik dengan yang diharapkan, umat Islam main memainkan peranannya dalam politik, sosial, perdagangan, pendidikan, dan segala sektor, bahkan peperangan. Pada akhirnya dengan perjuangan tersebut membuahkan kemerdekaan bagi bangsa Indonesia, walaupun keinginan untuk penerapan hukum Islam di Indonesia belum tercapai, disebabkan oleh beberapa faktor, terutama berbeda kepentingan antara elit politik Islam. Wallahu "alamu bi al Shawab.

${ }^{78}$ Baca, Karim, Islam dan Keindonesiaan, hlm. 67-70. 